\title{
Molecular analysis of predation by carabid beetles (Carabidae) on the invasive Iberian slug Arion lusitanicus
}

\author{
B.A. Hatteland ${ }^{1 *}$, W.O.C. Symondson ${ }^{2}$, R.A. King ${ }^{2+}$, \\ M. Skage ${ }^{1 \neq}$, C. Schander ${ }^{1}$ and T. Solhøy ${ }^{1}$ \\ ${ }^{1}$ Department of Biology, University of Bergen, Post Box 7803, 5020 Bergen, \\ Norway: ${ }^{2}$ Cardiff School of Biosciences, Biomedical Sciences Building, \\ Cardiff University, Museum Avenue, Cardiff, CF10 3AX, UK
}

\begin{abstract}
The invasive Iberian slug, Arion lusitanicus, is spreading through Europe and poses a major threat to horticulture and agriculture. Natural enemies, capable of killing A. lusitanicus, may be important to our understanding of its population dynamics in recently invaded regions. We used polymerase chain reaction (PCR) to study predation on A. lusitanicus by carabid beetles in the field. A first multiplex PCR was developed, incorporating species-specific primers, and optimised in order to amplify parts of the mitochondrial cytochrome c oxidase subunit 1 (cox1) gene of large Arion slugs, including A. lusitanicus from the gut contents of the predators. A second multiplex PCR, targeting $12 S r R N A \mathrm{mtDNA}$, detected predation on smaller Arion species and the field slug Deroceras reticulatum. Feeding trials were conducted to measure the effects of digestion time on amplicon detectability. The median detection times (the time at which $50 \%$ of samples tested positive) for A. lusitanicus and $D$. reticulatum DNA in the foreguts of Carabus nemoralis were $22 \mathrm{~h}$ and $20 \mathrm{~h}$, respectively. Beetle activity-densities were monitored using pitfall traps, and slug densities were estimated using quadrats. Predation rates on slugs in the field by C. nemoralis in spring ranged from 16-39\% (beetles positive for slug DNA) and were density dependent, with numbers of beetles testing positive being positively correlated with densities of the respective slug species. Carabus nemoralis was shown to be a potentially important predator of the alien A. lusitanicus in spring and may contribute to conservation biological control.
\end{abstract}

Keywords: Carabus nemoralis, Deroceras reticulatum, gut content analysis, multiplex PCR, predator-prey interactions

(Accepted 18 January 2011)

\footnotetext{
*Author for correspondence

Fax: + 4755584400

E-mail: bjorn.hatteland@bio.uib.no

tCurrent address: School of Biosciences, Geoffrey Pope Building, University of Exeter, Stocker Road, Exeter, EX4 4QD, UK

$\ddagger$ Current address: Centre for Ecological and Evolutionary Synthesis (CEES), University of Oslo, PO Box 1066 Blindern, 0316 Oslo, Norway
}

\section{Introduction}

Predator-prey interactions are an essential part of any understanding of the population dynamics of the species involved. The prey preferences of non-specialist generalist predators are determined by complex interactions between factors such as encounter rates, switching behaviour, relative densities of potential prey, functional responses, availability of refugia and the defensive capabilities of the prey (Begon et al., 2000; Symondson et al., 2002a). Analysis of predation in the field, where multiple prey species are available, can provide 
essential background information for evaluating potential biological control agents for pest species. Such analyses are particularly useful for identifying natural enemies that are capable of attacking alien species, such as the Iberian slug Arion lusitanicus Mabille (sensu Altena 1955) in Norway.

Arion lusitanicus (also recognised as A. vulgaris MoquinTandon 1855 (Anderson, 2005)) is spreading through large parts of northern Europe (von Proschwitz, 1992, 1994; Dolmen \& Winge, 1997; Grimm et al., 2000) and was first recorded in Norway in 1988 (von Proschwitz \& Winge, 1994). The species is causing major concerns for gardeners, horticulturalists and farmers (Hofsvang, 2003), causing damage to crops such as strawberries and devaluing grass fodder for cows. There is also a concern that these slugs may have negative effects on native slugs such as the closely related $A$. ater, by invading their habitats (von Proschwitz, 1997). The success of alien pests is sometimes explained by the enemy release hypothesis (Keane \& Crawley, 2002; Mitchell \& Power, 2003; Torchin et al., 2003), in which the pests thrive when released from native natural enemies that have evolved to feed on them. Populations of $A$. lusitanicus are reaching plague proportions in some areas (von Proschwitz, 1992), thus development of new pest management is necessary. Molluscicidal baits are the most commonly used control against gastropods, although formulations have sometimes been either too weak, so that gastropods do not ingest a lethal dose before they are sated, or too strong, which means they reject the baits immediately (Barker, 2002). Furthermore, molluscicides cause collateral damage to other organisms, especially methiocarb, which is poisonous for mammals such as dogs and hedgehogs (Bailey, 2002). Thus, there is a need to identify native predators that are capable of killing and consuming these alien slugs. Only then can pest management strategies be devised that foster these potentially useful natural enemies.

Many carabid beetles are opportunistic generalist predators and have been shown to be beneficial to agriculture as predators of pest species (Thiele, 1977; Luff, 1987; Lövei \& Sunderland, 1996; Kromp, 1999; Holland, 2002). Symondson (2004) reviewed carabids and other beetle groups as natural enemies of molluscs, concluding that many polyphagous predators in these groups are important gastropod predators. Many studies have focused on the generalist Pterostichus melanarius (Ayre, 2001; McKemey et al., 2001, 2003, 2004; Oberholzer \& Frank, 2003; Langan et al., 2004), which is a major predator of slugs in arable fields (Symondson et al., 1996, 2002a; Bohan et al., 2000). Pterostichus melanarius has been shown to aggregate to areas of high slug densities (Bohan et al., 2000) and to be capable of developing a semi-coupled relationship with slugs between years (Symondson et al., 2002a). Most work to date has been on the field slug Deroceras reticulatum, while only a few studies have dealt with A. lusitanicus (Paill, 2000, 2004; Paill et al., 2002; Oberholzer \& Frank, 2003).

The versatility of PCR-based methods for detecting predator-prey interactions is now well recognised and is the most practical approach where prey are soft bodied, leaving no recognisable hard parts in the guts or faeces of predators (Symondson, 2002). These techniques are highly sensitive and have been used to detect predation on a wide range of species (Zaidi et al., 1999; Agusti et al., 2003; Harper et al., 2005; Traugott \& Symondson, 2008). Slugs such as D. reticulatum and $A$. hortensis have been found to be detectable after approximately $30 \mathrm{~h}$ in the gut of the carabid beetle P. melanarius (Harper et al., 2005). Multiplex PCRs, in particular, provide an efficient means of disentangle trophic interactions by detecting many species at the same time in each predator gut sample (Harper et al., 2005; King et al. 2010a,b).

Here, our aim was to design and optimize multiplex PCRs to detect predation on arionid slugs, including the invasive Iberian slug A. lusitanicus, and to measuring rates of predation in the field. Symondson (2004) emphasized the need to identify key predator species that are numerous enough to affect prey populations. Carabus species are generally regarded as oligophagous specialists on earthworms and gastropods, with mouthparts adapted for killing and feeding on such prey (Hengeveld, 1980a,b; Evans \& Forsythe, 1985). In many parts of Europe, including Scandinavia, Carabus nemoralis Müller is widespread and common in agricultural landscapes (Lindroth, 1985; Turin et al., 2003). It is also active during the spring (Lindroth, 1985) when individuals of A. lusitanicus are small enough for the beetles to be able to prey upon them (Hatteland et al., 2010). Laboratory experiments have found that $C$. nemoralis is capable of killing and consuming $A$. lusitanicus up to $1.3 \mathrm{~g}$, with a preference for slugs $<1 \mathrm{~g}$ (Hatteland et al., 2010). These experiments found no preference for $D$. reticulatum over the more recently introduced A. lusitanicus. We, therefore, hypothesised that $C$. nemoralis has no specific preferences for any slug species within the Arion and Deroceras genera and that rates of predation, detected using PCR, would simply reflect relative population densities of different slug prey.

\section{Materials and methods}

\section{Field site}

The carabid beetles C. nemoralis, $P$. melanarius and $P$. niger were sampled at two sites, a meadow in Bergen $\left(60^{\circ} 38^{\prime} \mathrm{N}\right.$, $\left.5^{\circ} 34^{\prime} \mathrm{E}\right)$ and a site with strawberry patches surrounded by set-aside land in Askøy $\left(60^{\circ} 28^{\prime} \mathrm{N}, 5^{\circ} 12^{\prime} \mathrm{E}\right)$, western Norway. The molluscicide Ferramol ${ }^{\circledR}$ and the herbicide Roundup ${ }^{\circledR}$ were used in the latter field by the farmer. Temperature was measured hourly in the field by data logger (Dickson HT100) during the sampling periods.

\section{Beetles collected for gut content analysis}

Sampling was by dry pitfall traps arranged in arrays of eight traps at each sample point. Beetles trapped in any of the eight traps were pooled as one sample. In the meadow, the traps were arranged in a total of 21 circles randomly spread out across the field, where each circle of traps represented one sample with minimum distance of three meters between circles. However, at the site with strawberry patches, we used nine transects from surrounding set-aside land into the strawberry patches. Each transect consisted of 4-8 sampling points, depending on the size of the respective strawberry patch, with four meters between each sampling point (fig. 1). Half of the sample points were set up in the set-aside (meadow or grassland) and half were set up within a strawberry patch. A total of 57 sample points were used at this site, each comprised of eight traps in double lines (456 pitfall traps in total).

Traps were plastic cups, $7-\mathrm{cm}$ wide $\times 9.5-\mathrm{cm}$ deep, buried to the rim and covered by a metal roof $c a .2 \mathrm{~cm}$ above the rim. Each trap had a $2.4 \mathrm{~mm}$ mesh insert through which smaller prey could fall, reducing potential predation by the beetles after being caught. The traps were emptied twice per day, in 

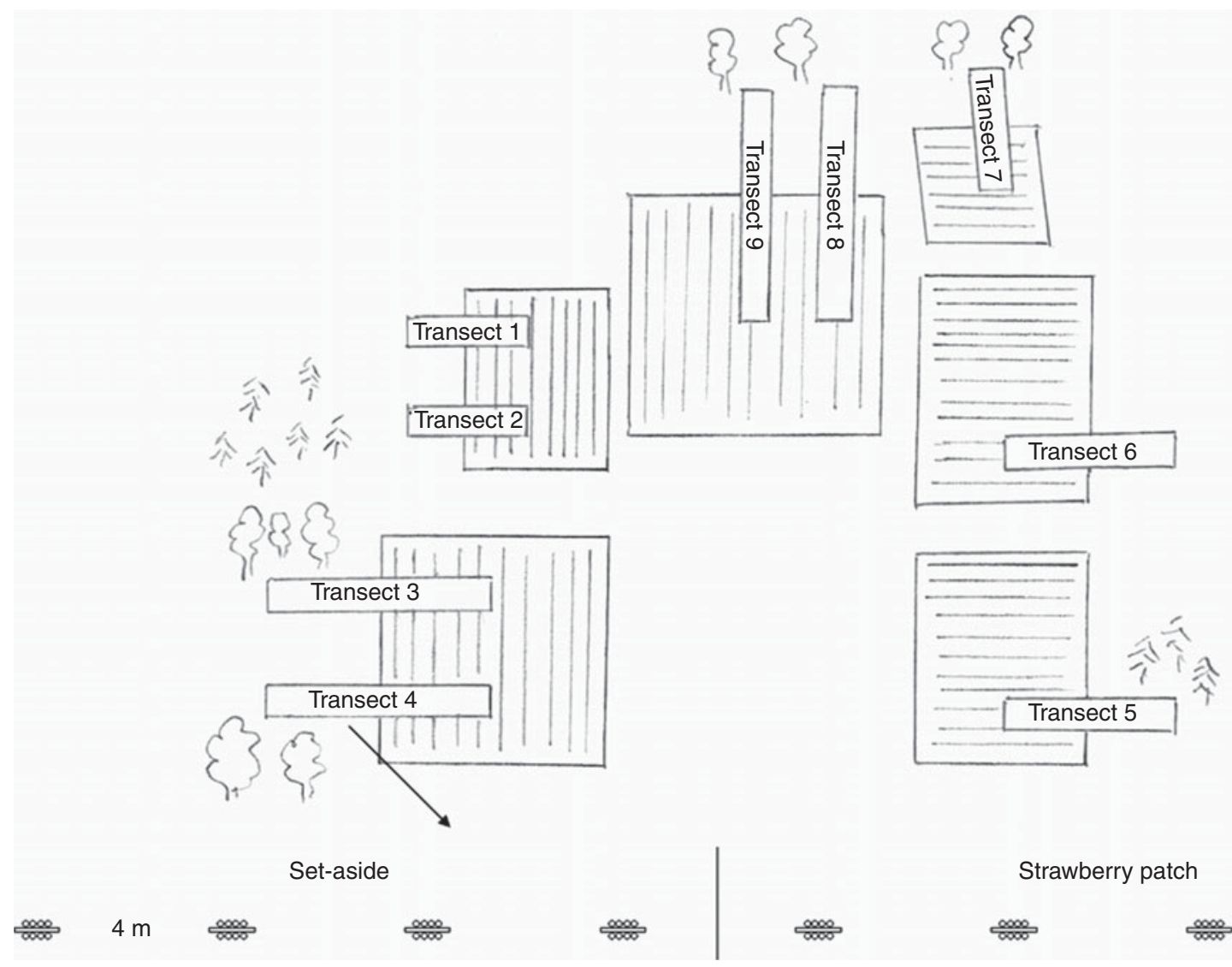

Fig. 1. Map of the strawberry patches surrounded by set-aside land at the Askøy site outside Bergen. The strawberry patches are represented as squares while the sampled transects are represented as rectangles. A schematic view of a transect is given below the map with pitfall traps represented as circles and searching plots for gastropods represented as rectangles. The line in the middle of the transect represents the edge of the strawberry patch.

the morning and in the evening, to minimise digestion times and possible predation within the traps. In the meadow, pitfall trapping was performed from 13 May to 30 June and 4 September to 7 October 2006, plus a short supplementary period from 21 June to 28 June in 2007. The strawberry site in Askøy was sampled from 24 April to 1 May and from 18 September to 27 September 2007. Beetles were transported to the laboratory and killed at $-20^{\circ} \mathrm{C}$ in spacious plastic boxes with $\mathrm{ca} .2 \mathrm{~cm}$ of sphagnum moss peat to reduce regurgitation due to stress. The beetles were then removed from the boxes into individual plastic tubes and stored at $-80^{\circ} \mathrm{C}$. Since pitfall trapping is not an absolute measure of density (Thiele, 1977; Luff, 1982, 2002), we use the term 'activity-density' thorough this paper when referring to the abundance of beetles.

\section{Molluscs sampled for field density analyses}

The field density of slugs and snails were determined in 109 quadrats associated with each cluster of pitfall traps. In addition, eggs of $A$. lusitanicus were counted in the field. Eleven, ten, ten and 21 quadrats were sampled in the meadow site at 11 May 2006, 8 June 2006, 12 October 2006 and 1 July 2007, respectively. All the quadrats used in the meadow site were $50 \times 50 \mathrm{~cm}$. Furthermore, 57 quadrats, each $20 \times 125 \mathrm{~cm}$, were sampled in the strawberry site, including set-aside land.
Each quadrat was situated $50 \mathrm{~cm}$ from each set of eight pitfall traps representing one sample point. The vegetation within the quadrat was thoroughly searched for molluscs and was then cut $c a .2 \mathrm{~cm}$ above ground level and the ground searched. Finally, the remaining moss was stripped away, and we searched carefully around any plant bases remaining. We made an attempt at the strawberry site to locate molluscs lying below the soil surface by taking one circular soil sample of $10 \mathrm{~cm}$ depth and $10 \mathrm{~cm}$ in diameter from each quadrat, which was then hand sorted. All molluscs were counted and weighed to the nearest $0.1 \mathrm{~g}$ except slugs $<0.1 \mathrm{~g}$, which were denoted as $0.05 \mathrm{~g}$. The slugs were released after weighing at the points where they were collected to avoid locally reducing populations.

\section{Feeding experiments}

Deroceras reticulatum slugs and juvenile slugs of A. lusitanicus, as well as C. nemoralis beetles, were sampled along the perimeter of the meadow field. Slugs were maintained in plastic bags with ca. $2 \mathrm{~cm}$ of sphagnum moss peat at $4-6^{\circ} \mathrm{C}$ prior to the feeding experiments. The beetles were kept at $14^{\circ} \mathrm{C}$ in a climate chamber (RUMED ${ }^{\circledR}$ Rubarth Apparate $\mathrm{GmbH}$ ), simulating the light conditions from the field following a light intensity regime of 50\% from 6:00 to 
Table 1. Primers $\left(5^{\prime}-3^{\prime}\right)$ for detection of slugs in carabid beetles foreguts.

\begin{tabular}{|c|c|c|c|c|c|c|}
\hline Multiplex & Species & Primer & Primer sequence & $\begin{array}{l}\text { Fragment } \\
\text { size (bp) }\end{array}$ & $\begin{array}{c}\text { Annealing } \\
\text { temperature }\left({ }^{\circ} \mathrm{C}\right)\end{array}$ & Reference \\
\hline \multirow[t]{5}{*}{ Cox1 } & \multirow{2}{*}{$\begin{array}{l}\text { Arion } \\
\quad \text { lusitanicus }\end{array}$} & A.1.-Co1-F1 & GCССССАТСТTTAСТTTTACTTATTTGСТСС & \multirow[t]{2}{*}{310} & \multirow[t]{2}{*}{51} & \multirow[t]{2}{*}{ New } \\
\hline & & $\begin{array}{l}\text { A.1.-Co1- } \\
\text { R2 }\end{array}$ & $\begin{array}{l}\text { GTATGGTAATAGCCCCCGCCAATACG - } \\
\text { FAM }\end{array}$ & & & \\
\hline & \multirow[t]{2}{*}{ A. ater } & $\begin{array}{l}\text { A.a.-Co1-F- } \\
\text { new }\end{array}$ & CACCACTGAGAGGAGCC & \multirow[t]{2}{*}{225} & \multirow[t]{2}{*}{51} & \multirow[t]{2}{*}{ New } \\
\hline & & $\begin{array}{l}\text { A.a.-Co1- } \\
\text { R1 }\end{array}$ & GCTCCAGCCAATACAGGTAAAG & & & \\
\hline & A. rufus & $\begin{array}{l}\text { A.a.-Co1- } \\
\text { R1 }\end{array}$ & GCTCCAGCCAATACAGGTAAAG - FAM & 362 & 51 & New \\
\hline \multirow[t]{3}{*}{$12 S r R N A$} & \multirow{2}{*}{$\begin{array}{l}\text { Deroceras } \\
\quad \text { reticulatum }\end{array}$} & DR11F & CTATACACAATTTTTAAATAAGC & \multirow[t]{2}{*}{109} & \multirow[t]{2}{*}{53} & \multirow{3}{*}{$\begin{array}{c}\text { Dodd, } \\
2004 \\
\text { Dodd, } \\
2004\end{array}$} \\
\hline & & DRF29RC & GTCTCTGGTTTATCTATTATTGGT & & & \\
\hline & Arion spp. & Ai1F & CACATAAATGATAGTCACC & 221 & 53 & \\
\hline
\end{tabular}

FAM, fluorescent label.

$8: 00,100 \%$ from $8: 00$ to $20: 00$ and $50 \%$ from $20: 00$ to $22: 00$ followed by darkness from 22:00 to 6:00. The beetles were maintained on earthworms (Lumbricus rubellus) then starved for ten days prior to the feeding experiments. Feeding experiments were performed in Petri dishes containing moistened filter paper with two live slugs per dish under the same climate conditions as the starvation period. Two slugs were chosen to increase the probability of predation within a 2-h feeding period. Beetles were killed in batches of eight beetles (five males and three females) at $10 \mathrm{~h}, 20 \mathrm{~h}, 40 \mathrm{~h}$ and $60 \mathrm{~h}$ post feeding, and stored at $-80^{\circ} \mathrm{C}$. Unfed beetles were kept as negative controls and non-feeding beetles were discarded from the experiment.

\section{Beetle dissections}

The beetles were defrosted then dissected. The foreguts were removed, weighed and stored in microfuge tubes at $-80^{\circ} \mathrm{C}$ prior to DNA extraction. Forceps and scalpel was sterilized between beetles by cleaning in $96 \%$ ethanol and open flame.

\section{DNA extractions}

DNA was extracted from beetle foreguts and non-target organisms for the cross-amplification test using the DNeasy Blood \& Tissue Kit (Qiagen), following the manufacturer's instructions. Extraction negatives (no tissue) were included for all sets of extractions to test for possible contamination during the extraction process. Extractions were stored in elution buffer at $-80^{\circ} \mathrm{C}$. DNA was extracted from mollusc foot fringes using the E.Z.N.A. tissue kit (Omega Bio-Tek) following manufacturer's instructions and stored in elution buffer at $4^{\circ} \mathrm{C}$.

\section{Primer design}

The universal invertebrate primers LCO1490 and HCO2198 designed by Folmer et al. (1994) were used to amplify the cytochrome c oxidase subunit 1 (cox1) gene of A. lusitanicus, A. ater and A. rufus. Each PCR was conducted in $25 \mu \mathrm{l}$, containing $12.5 \mu \mathrm{l}$ Promega PCR Mastermix (Promega), $1.0 \mu \mathrm{l}$ of each primer $(10 \mu \mathrm{M}), 2.0 \mu \mathrm{l}$ DNA (10:1 diluted) and
$5.5 \mu$ distilled $\mathrm{H}_{2} \mathrm{O}$. PCRs were carried out in a MJ Research PTC220 Peltier thermal cycler, with cycling conditions of $94^{\circ} \mathrm{C}$ for $2 \mathrm{~min}$, followed by five cycles of $92^{\circ} \mathrm{C}$ for $60 \mathrm{~s}, 45^{\circ} \mathrm{C}$ for $1.5 \mathrm{~min}, 72^{\circ} \mathrm{C}$ for $1.5 \mathrm{~min}$, then 30 cycles of $92^{\circ} \mathrm{C}$ for $30 \mathrm{~s}, 50^{\circ} \mathrm{C}$ for $60 \mathrm{~s}$ and $72^{\circ} \mathrm{C}$ for $50 \mathrm{~s}$ and a final cycle of $72^{\circ} \mathrm{C}$ for $7 \mathrm{~min}$. PCR products were checked and visualized on $1 \%$ agarose gels following standard procedures, before purification with ExoSap-IT (GE Healthcare) and sequenced with version 3.1 Big Dye terminator chemistry on an ABI3700 capillary sequencer (Applied Biosystems). The sequences were aligned using the software BioEdit, including the multiple alignment function of CLUSTAL W (Hall, 1999). Species-specific primers were designed for A. lusitanicus, A. ater and A. rufus (table 1) by using the software PRIMER 3 (Rozen \& Saletsky, 1996-1998).

\section{PCR amplification and optimization}

To avoid false negatives, extractions were tested by PCR for the presence of amplifiable DNA using general invertebrate primers for a $710 \mathrm{bp}$ fragment of the mitochondrial cox 1 gene (Folmer et al., 1994). PCRs were performed in $12.5 \mu \mathrm{l}$, containing $6.25 \mu \mathrm{l} \mathrm{GoTaq}$ (Promega) Mastermix, $0.5 \mu \mathrm{l}$ of each primer

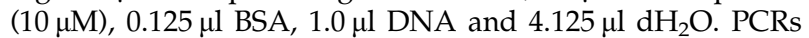
were carried out in a MJ Research PTC220 Peltier thermal cycler, with cycling conditions of $94^{\circ} \mathrm{C}$ for $1.5 \mathrm{~min}$, followed by five cycles of $94^{\circ} \mathrm{C}$ for $30 \mathrm{~s}, 45^{\circ} \mathrm{C}$ for $1.5 \mathrm{~min}, 72^{\circ} \mathrm{C}$ for $1 \mathrm{~min}$, then 35 cycles of $94^{\circ} \mathrm{C}$ for $30 \mathrm{~s}, 51^{\circ} \mathrm{C}$ for $1.5 \mathrm{~min}$ and $72^{\circ} \mathrm{C}$ for $1 \mathrm{~min}$ and a final cycle of $72^{\circ} \mathrm{C}$ for $5 \mathrm{~min}$. Any samples that failed to amplify were excluded from further analyses.

Two diagnostic multiplex PCRs were used to simultaneously screen each predator gut sample for the presence of multiple slug species. The first multiplex PCR (cox1 multiplex PCR) amplified short fragments of the cox 1 gene from $A$. lusitanicus, $A$. ater and $A$. rufus. The assay was optimized for gut content analysis by adding the PCR facilitator bovine serum albumin (BSA), which has been found to overcome PCR-inhibition in gut-content samples (Juen \& Traugott, 2006). The second multiplex PCR targeting the small mitochondrial ribosomal gene (12S rRNA multiplex PCR) and contained primers for D. reticulatum and an Arion genus-specific primer pair (Dodd, 2004: table 1). The latter primer pair amplifies different sized fragments for each Arion 
Table 2. Cross-amplification tests on non-target prey, target prey and predators using each of the two multiplex PCRs (cox1 and 12S rRNA) separately.

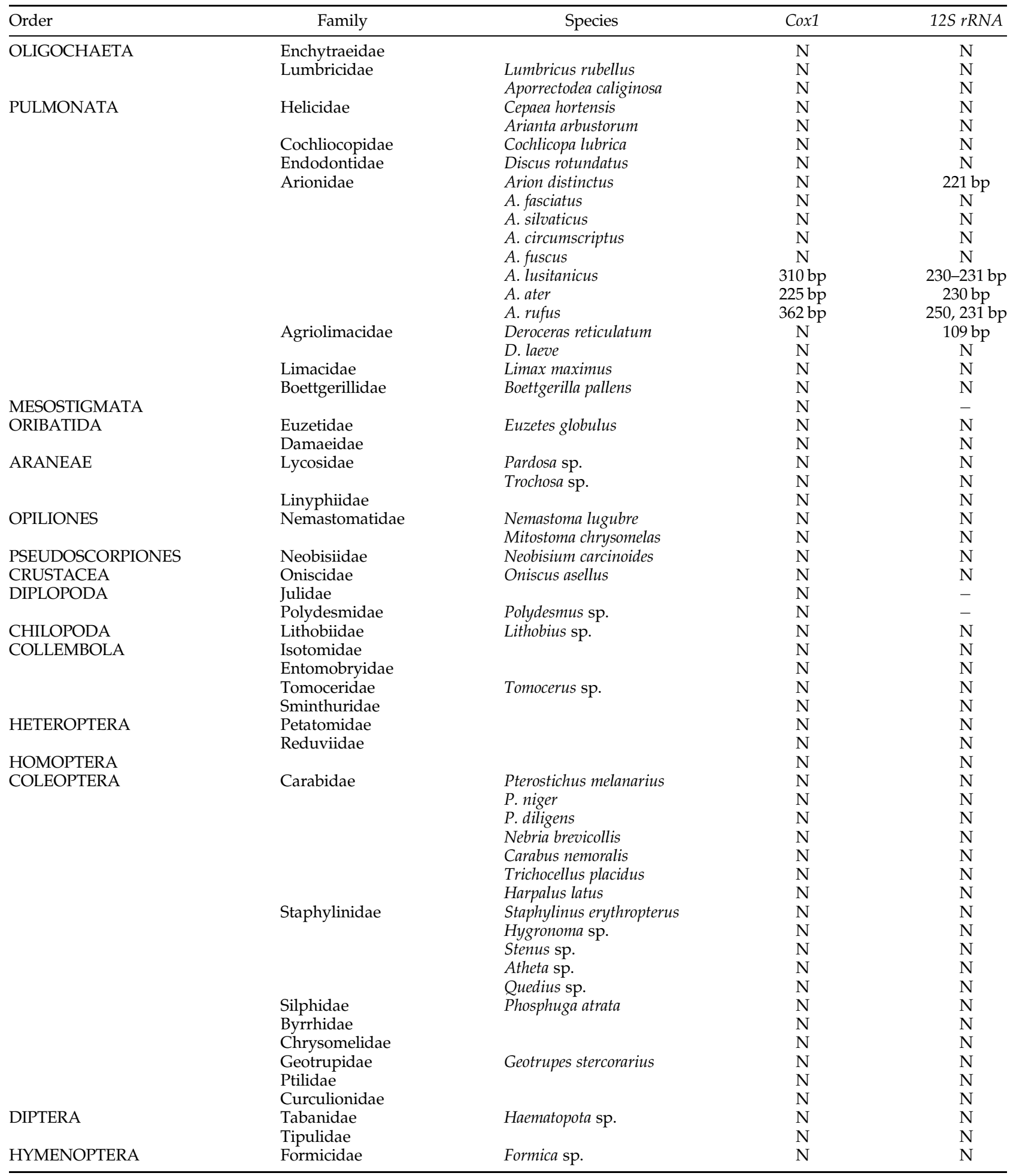

- , not tested; $\mathrm{N}$, no amplification.

species (Dodd, 2004; Harper et al., 2005). PCRs were conducted in $12.5 \mu \mathrm{l}$ volumes, containing $6.25 \mu \mathrm{l}$ GoTaq (Promega) or Qiagen Multiplex PCR Mastermix, $0.25 \mu \mathrm{l}$ of each primer

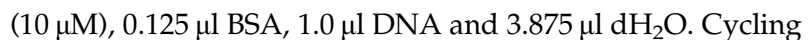
conditions for the cox 1 multiplex PCR (table 1) were $94^{\circ} \mathrm{C}$ for $2 \mathrm{~min}$, followed by 30 cycles of $92^{\circ} \mathrm{C}$ for $30 \mathrm{~s}, 51^{\circ} \mathrm{C}$ for $1 \mathrm{~min}$ 
and $72^{\circ} \mathrm{C}$ for $50 \mathrm{~s}$. A final cycle of $68^{\circ} \mathrm{C}$ for 5 min was used when applying Qiagen Multiplex PCR Mastermix, while denaturing for $2 \mathrm{~min}$, annealing for $30 \mathrm{~s}$, and extension at $70^{\circ} \mathrm{C}$ was carried out when using the GoTaq PCR Mastermix. Cycling conditions for the $12 S$ rRNA multiplex PCR were $94^{\circ} \mathrm{C}$ for $15 \mathrm{~min}$, followed by 35 cycles of $94^{\circ} \mathrm{C}$ for $30 \mathrm{~s}, 53^{\circ} \mathrm{C}$ for $30 \mathrm{~s}$ and $72^{\circ} \mathrm{C}$ for $1 \mathrm{~min}$, and a final cycle of $72^{\circ} \mathrm{C}$ for $10 \mathrm{~min}$. All PCRs included positive (target prey) and negative controls consisting of PCR reagents with distilled water as substitute for DNA. PCR products were visualized on $1-2 \%$ agarose gels following standard procedures. In some cases, we checked the absolute amplicon size by using $\mathrm{Hi}-\mathrm{Di}$ formamide and $0.25 \mu$ l GESESCAN 350 (ROX) size standard (both Applied Biosystems) and then separated using a 3130xl Genetic Analyzer (Applied Biosystems). The software Genemapper 4.0 (Applied Biosystems) was used to score electropherograms.

\section{Cross-amplification tests on non-target organisms}

All primers were tested for cross-amplification using DNA extracted from 54 potential prey taxa plus the three carabid species analysed in this study (table 2). Most of the taxa were common in the field where the beetles were sampled. Others were selected in order to increase the diversity and breadth of taxa. The non-target organisms were tested individually with one multiplex PCR at a time. At least one specimen was tested for each taxon.

\section{Statistical analysis}

All statistical analyses were performed using $\mathrm{R}$ version 2.8.0 (R Development Core Team, 2008). Generalized linear models (GLMs) were used to analyze the data from the controlled feeding experiments. As the data consisted of PCR-negatives and PCR-positives, a binomial distribution was used in the models. Median detection times (the time at which $50 \%$ of beetles tested positive, equivalent to the detectability half-life of Chen et al., 2000) were calculated from the binomial regression equations. GLMs were also applied to test if the detection of slug DNA in beetle foreguts were significantly different between species of slugs and between sexes of beetles. The latter analyses were carried out using presence and absence of DNA as the response variables and slug species and beetle sex as explanatory variables.

GLM was also used to analyse predation in the field by using a binomial distribution of the presence-absence data of slug DNA in field-caught beetles. The proportions of slugpositive beetles were used as the response variable, while the abundance of $A$. lusitanicus (defined as the abundance of A. lusitanicus as a proportion of the total abundance of all target slug species: A. lusitanicus, $A$. distinctus, A. ater $\times A$. rufus and $D$. reticulatum) was used as the explanatory variable.

Finally, generalised linear mixed-effect models (GLMMs) were used to test the differences in density of slugs and beetles in strawberry patches versus set-aside land. This was done by using the function 'glmmPQL' available in the package 'MASS' in R. The different transects were used as a random factor. GLMM approximation for analysing non-normal data such as counts has recently been reviewed by Bolker et al. (2008). The quasipoisson distribution was used due to overdispersion in the count data, as suggested by diagnostic plots (leverage, normal Q-Q, fitted and scale location), and by comparing the residual deviance with degrees of freedom.
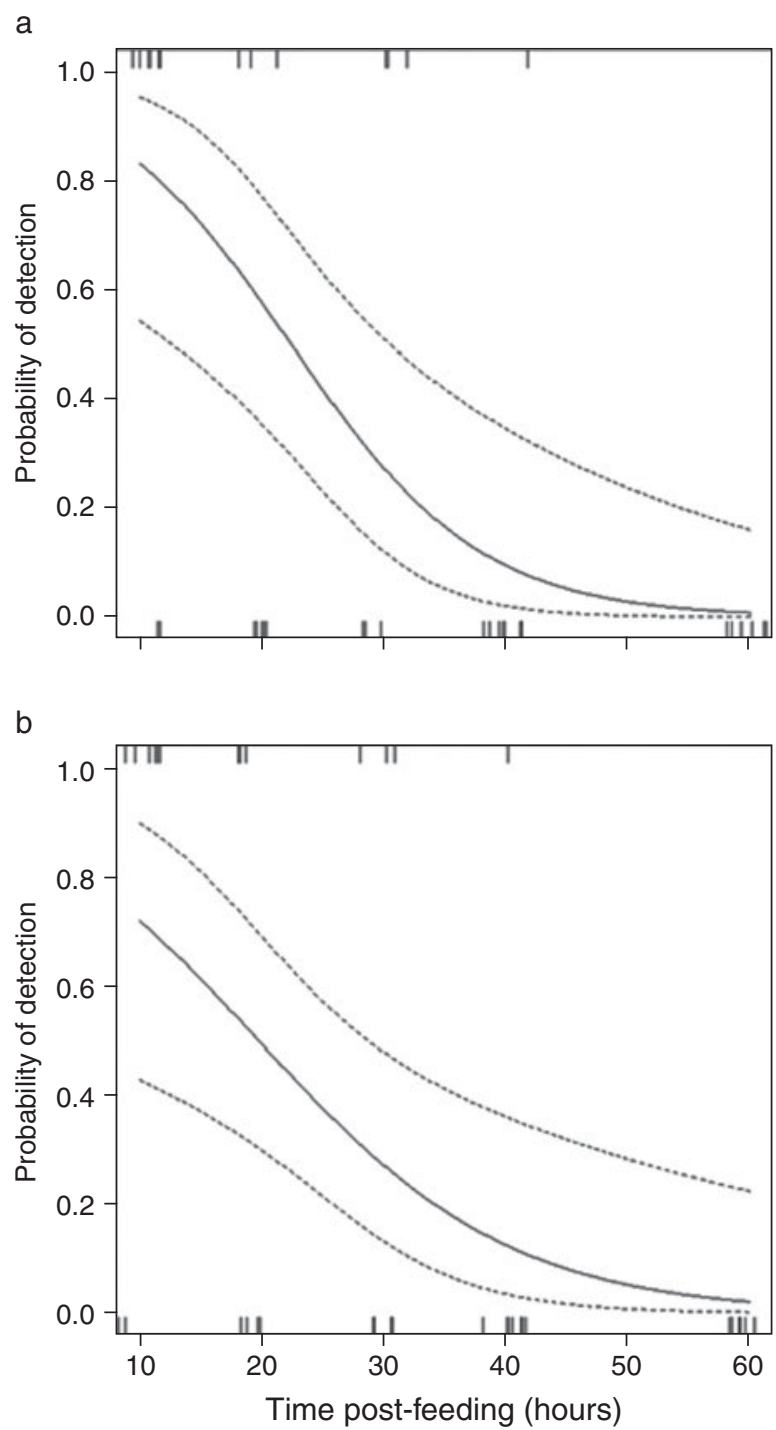

Fig. 2. Detection period of prey DNA in the foreguts of Carabus nemoralis fed with Arion lusitanicus and Deroceras reticulatum using the $\operatorname{cox} 1$ and $12 S$ rRNA multiplex PCR, respectively. The solid line represents the binomial model, while the dotted lines represent the upper and lower 95\% confidence limits. The vertical lines represent the replicates and one line may in some cases consist of more than one replicate. (a) The detection of $A$. lusitanicus (median detection period $=22.4 \mathrm{~h}$ ). (b) The detection of $D$. reticulatum (median detection period $=19.7 \mathrm{~h}$ ).

\section{Results}

\section{Primer specificity and sensitivity}

None of the 57 non-target prey and predator species were amplified using either the cox1 or $12 S$ rRNA multiplex PCRs (table 2). The $12 S$ rRNA multiplex PCR yielded $221 \mathrm{bp}$ and $109 \mathrm{bp}$ amplicons for the target species $A$. distinctus and $D$. reticulatum, respectively, when using fluorescent primers, which are the same as for British specimens (Harper et al., 2005). However, no amplification of other small arions like A. silvaticus was achieved. Furthermore, the general Arion primers in the $12 S r R N A$ multiplex PCR could not accurately 
Table 3. Predation in both fields by Carabus nemoralis (percentages of PCR-positives) compared with densities and mass of Arion lusitanicus, $A$. ater introgressed with $A$. rufus, A. distinctus and Deroceras reticulatum.

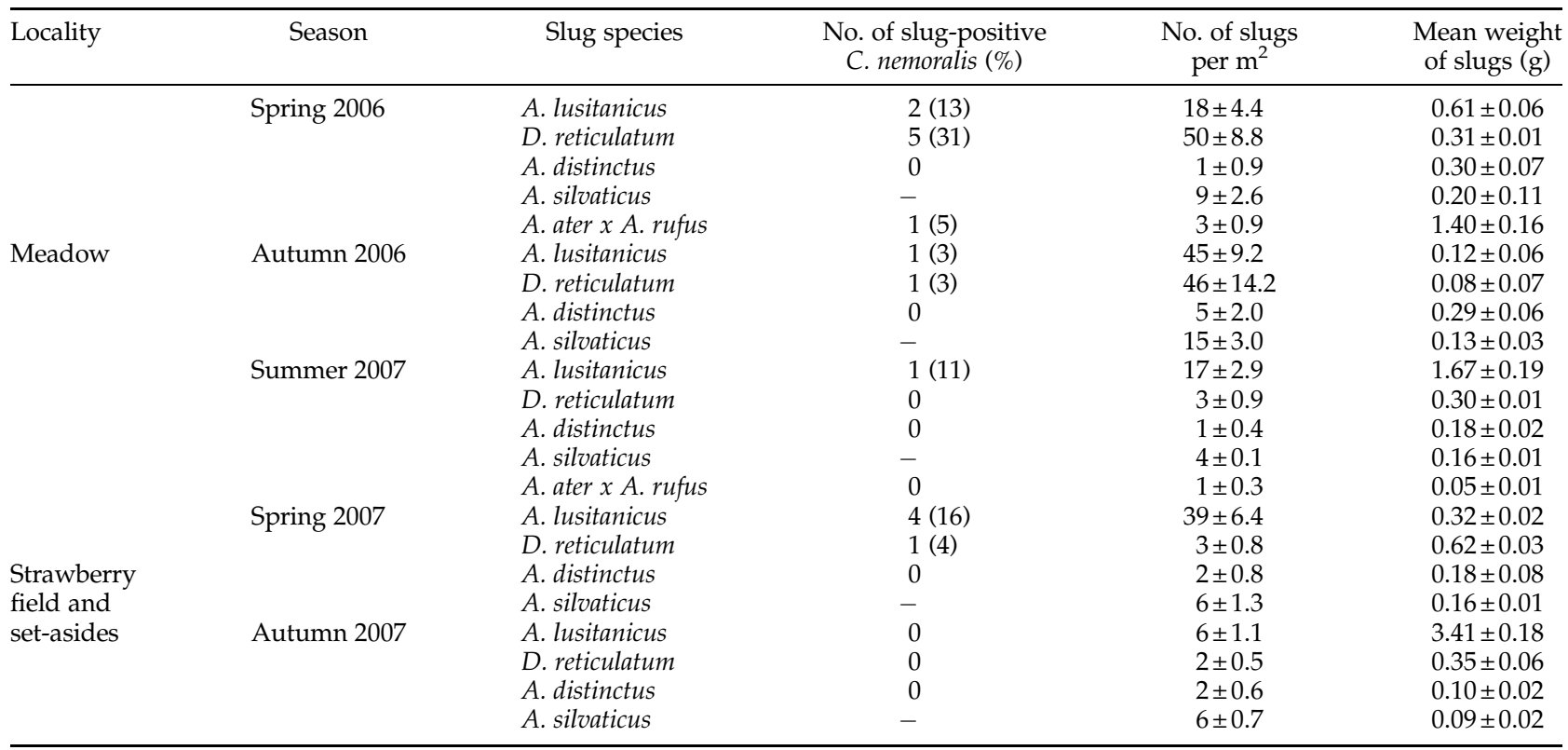

- , no data available; \pm , standard errors.

separate the large Arion species; hence, the design and inclusion of the $\operatorname{cox} 1$ multiplex PCR. The latter provided clear separation of the three closely related, large arionids, A. ater, A. rufus and A. lusitanicus.

\section{Feeding trials with Arion lusitanicus and Deroceras reticulatum}

The maximum detection period of $A$. lusitanicus and $D$. reticulatum DNA in the foreguts of $C$. nemoralis was up to $40 \mathrm{~h}$ post-feeding with median detection periods of 22.4 and $19.7 \mathrm{~h}$, respectively (fig. 2). Detectability of the two slug species over time was not significantly different $(P=0.995$, binomial GLM); neither was there a difference between male and female beetles $(P=0.455$, binomial GLM).

\section{Slug densities}

The most common slug species in the present study were A. silvaticus, $A$. lusitanicus, $A$. distinctus and D. reticulatum (table 3). Other molluscs found in the study sites were Arion ater introgressed with $A$. rufus (based on a combination of morphology and the cox 1 multiplex PCR Hatteland et al., in preparation), A. circumscriptus, A. fasciatus, A. intermedius, Deroceras panormitanum, D. laeve, Boettgerilla pallens, Arianta arbustorum, Cepaea hortensis, Cochlicopa lubrica, Nesovitrea hammonis, Trochulus hispidus and Discus rotundatus. In the meadow, $D$. reticulatum was the most numerous species, but $A$. silvaticus and $A$. lusitanicus were also common. On the other hand, $A$. lusitanicus was more numerous compared with other species at the strawberry site, co-occurring with $C$. nemoralis in higher numbers within the surrounding set-aside land (fig. 3 ). However, only the density of $A$. lusitanicus was significantly higher in the set-asides compared with the strawberry patches
$(P<0.001, \mathrm{GLMM})$. These findings are mainly based on sampling the vegetation down to the soil surface. We only found six slugs in the subsurface soil samples at the strawberry site; three specimens of $B$. pallens plus single specimens of A. lusitanicus, A. silvaticus and D. reticulatum.

\section{Predation in the field}

In total, we collected 113 adult carabids, of which C. nemoralis was the most numerous (table 4). The mean foregut weights of 40 field-collected $C$. nemoralis were $12 \pm 2 \mathrm{mg}$ and $19 \pm 4 \mathrm{mg}$ for males and females, respectively.

Predation rates by $C$. nemoralis in all the fields together ranged from $16 \%$ to $39 \%$ slug-positive beetles in spring, of which $7 \%$ contained DNA from two slug species. In addition, predation by $P$. niger ranged from $10 \%$ to $20 \%$. Furthermore, predation by $C$. nemoralis was density related with beetles feeding on the most abundant slug species (GLM, $P=0.0340$; fig. 4), which was often A. lusitanicus (table 3). In autumn 2006, only $3 \%$ of $C$. nemoralis were positive for A. lusitanicus and $D$. reticulatum, even though both species were present in high numbers as eggs $\left(82 \pm 40\right.$ per $\mathrm{m}^{2}$ s.e.) and newly hatched juveniles.

\section{Discussion}

The main finding was that $C$. nemoralis was a consumer of the invasive $A$. lusitanicus, the 'plague' slug that is causing severe damage to crops through much of northern Europe. Importantly, the data showed that alien species were not avoided and that the different slug species were eaten seemingly in proportion to their density, with little discrimination between species.

Previous studies have shown that many factors affect detection times of prey DNA in the guts of predators. The 
a

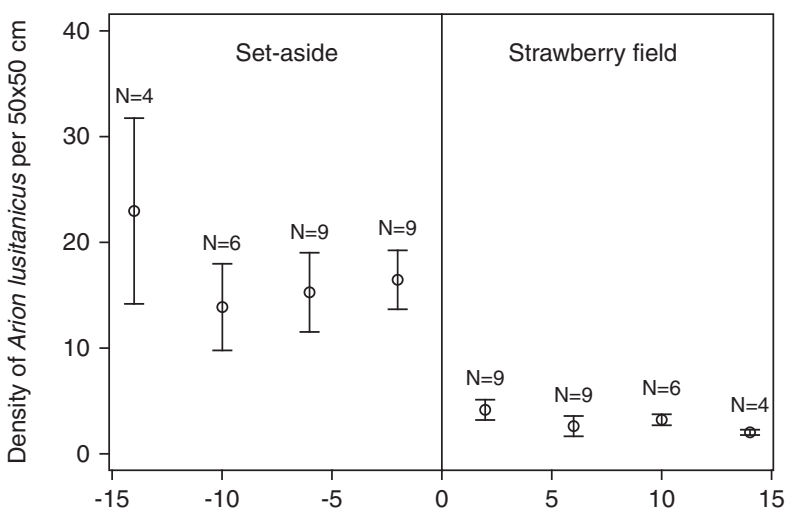

b

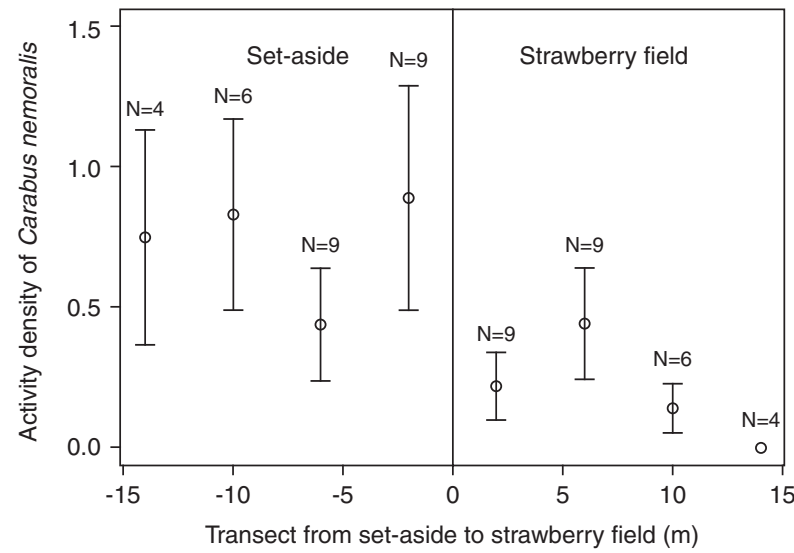

Fig. 3. Densities of slugs and beetles in nine transects from surrounding set-asides to the strawberry patches in spring 2007. The plots along transects were $4 \mathrm{~m}$ apart and were sampled once in late April. (a) Density of Arion lusitanicus per $0.25 \mathrm{~m}^{2}$. (b) Activitydensity of Carabus nemoralis per sample point (eight traps for one week). The vertical line represents the edge of the strawberry patch. Error bars are given as standard errors.

fragments amplified by primers used in the present study were about $300 \mathrm{bp}$ in length, which is set as a preferred upper limit, since larger fragments degrades faster than shorter fragments (Symondson, 2002; King et al., 2008). The choice of predator taxa has also been found to significantly influence the detectability (Chen et al., 2000; Ma et al., 2005; Read et al., 2006; Greenstone et al., 2007; Harwood et al., 2007; Traugott \& Symondson, 2008), even in related species within the Carabidae family (von Berg et al., 2008a). However, the detection period of $D$. reticulatum in C. nemoralis in the present study was similar to the results obtained in other studies (Dodd, 2004; Harper et al., 2005) when using P. melanarius. Many other factors also influence the detection of prey DNA, such as temperature (Hoogendoorn \& Heimpel, 2001; von Berg et al., 2008a), weather (von Berg et al., 2008b), combination of prey DNA (Harper et al., 2005) and the amount of prey DNA ingested (de Leon et al., 2006; King et al., 2010b). Our calibrating feeding experiment with A. lusitanicus and $D$. reticulatum makes it possible to compare predation on these species in the field directly without adjustment since detection times were not significantly different. Furthermore,
Table 4. The total number of adult carabid beetles used for screening of slug DNA.

\begin{tabular}{lccc}
\hline & $\begin{array}{c}\text { Pterostichus } \\
\text { melanarius }\end{array}$ & $\begin{array}{c}\text { Pterostichus } \\
\text { niger }\end{array}$ & $\begin{array}{c}\text { Carabus } \\
\text { nemoralis }\end{array}$ \\
\hline Spring 2006 & 2 & 0 & 16 \\
Autumn & 0 & 1 & 31 \\
$\quad 2006$ & 1 & 5 & 25 \\
$\begin{array}{l}\text { Spring 2007 } \\
\text { Summer }\end{array}$ & 3 & 10 & 9 \\
$\quad$ 2007 & 0 & 7 & 3 \\
$\quad$ 2007 & 6 & 23 & 84 \\
\hline Total & & & \\
\hline
\end{tabular}

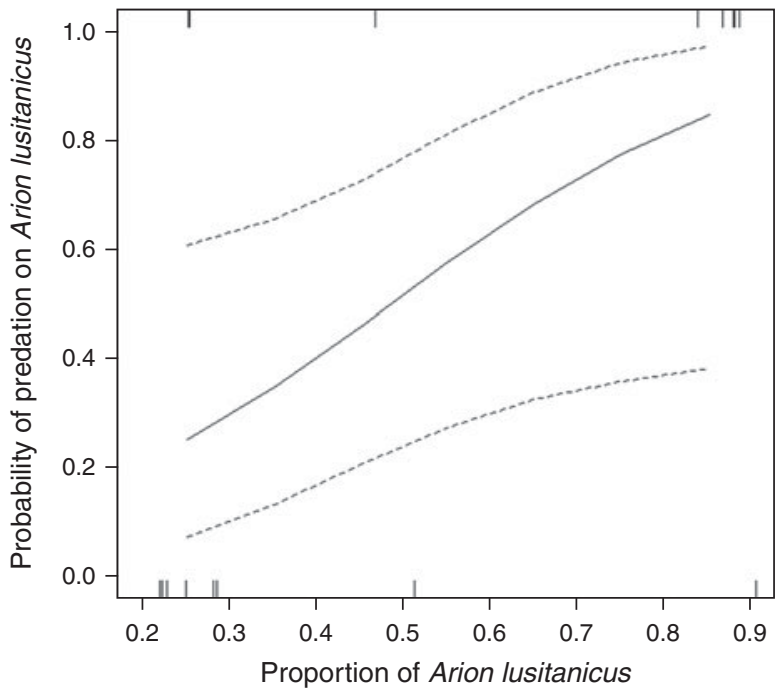

Fig. 4. Predation by Carabus nemoralis on Arion lusitanicus in response to the proportion of $A$. lusitanicus compared with the total abundance of all target slug species (Arion distinctus, A. lusitanicus, A. ater, A. rufus and Deroceras reticulatum) across all dates and both field sites. The solid line represents the binomial model, while the dotted lines represent the $95 \%$ confidence limit. The vertical ticks represent the replicates (number of positives and negatives for each dataset), and one line may in some cases consist of more than one replicate.

the detection time in male and female $C$. nemoralis was not significantly different; thus, predation by field-caught beetles may be interpreted without considering sex. This is in accordance with Dodd (2004), who did not find any significant differences in detection of $D$. reticulatum in male and female P. melanarius.

The method we applied for sampling of slugs does not give absolute numbers, since only the vegetation down to the soil surface was sampled. Thus, the accuracy of the methods is probably affected by the vegetation and soil structure. There are reasons to assume that slugs will be found deeper down in the soil in arable fields than in meadows (lower vegetation cover and coarser soil particles in arable fields as compared to meadows). However, very few slugs were found in the analysed soil samples in the present study, leading us to conclude that most slugs were located on the soil surface or in the vegetation, at least in the fields included in our study. 
As the soil at the study sites was compacted, we believe that sampling down to the soil surface recovered most slugs in the area, at least during the part of the year when they are active.

The present study is the first to demonstrate that $C$. nemoralis and $P$. niger feed on the invasive Iberian slug, A. lusitanicus, as well as D. reticulatum in the field. Carabus nemoralis fed on slugs with no obvious prey preference, and predation on A. lusitanicus occurred mainly in spring when juveniles were present. Hence, $C$. nemoralis has potential in conservation biological control since this carabid is most active in spring (Lindroth, 1985). In addition, P. niger was found to be a predator of $A$. lusitanicus, as also suggested by laboratory experiments (Hatteland et al., 2010). Paill $(2000,2004)$ found the same to be true for $C$. violaceus and $P$. melanarius, respectively, feeding on $A$. lusitanicus in June and in early autumn. However, Pterostichus species are more restricted in the size of prey taken compared to larger and more specialised predators, such as Carabus spp. (Hatteland et al., 2010). The threshold of slug size for $P$. niger and $P$. melanarius seems to be approximately $100 \mathrm{mg}$, based on laboratory experiments (McKemey et al., 2001; Hatteland et al., 2010) and field studies (Paill, 2004), while C. nemoralis consumes slugs of up to $1 \mathrm{~g}$ (Hatteland et al., 2010). Surprisingly, we did not find many positive beetles in autumn, although slugs were abundant as newly hatched juveniles or eggs. The explanation might be that the beetles find it difficult to find newly hatched slugs, and their eggs (reviewed in Symondson, 2004), and/or alternative prey, may have been abundant at this time.

Temperature can also affect rates of predation on slugs (Ayre, 2001). The activity threshold of C. nemoralis has been found to be $4^{\circ} \mathrm{C}$, and activity is greater when temperatures rise in spring, while activity is not correlated with temperature later in the season (Weber \& Heimbach, 2001). In our study area, the diel mean temperature at ground level was $10.6 \pm 0.2^{\circ} \mathrm{C}$ (s.e.) in the spring and $14.2 \pm 0.2^{\circ} \mathrm{C}$ in the summer of 2007 as measured by a data logger, which suggests sufficient temperatures for beetle activity. The activity-density of beetles was low at the strawberry site compared with the meadow, which might reflect the different densities of these carabids in the two fields surveyed. However, many factors tend to affect pitfall catches which make it hard to compare different results (Adis, 1979; Spence \& Niemelä, 1994; Luff, 2002). Activity of beetles may often be related to satiation levels; thus, pitfall catches can be used as a measure of prey availability (Szyszko et al., 2004). Satiation, however, is not always linked to predation. Pterostichus melanarius has been found to even kill prey when satiated (Hagley et al., 1982). In addition, pesticides were used in our strawberry site. This, as well as a much higher degree of disturbance in the field compared to the meadow, may explain the lower numbers of beetles in the strawberry patches and the surrounding set-asides.

Unfortunately, our method of detecting prey remains in the predators does not discriminate between predation and scavenging (Foltan et al., 2005). Pterostichus melanarius has been found to prefer dead slugs over live slugs, although preference changed to living prey the longer the decaying process progressed (Calder et al., 2005; Foltan et al., 2005). Another finding indicating carrion preference was that $P$. melanarius seems to orientate towards slugs by responding to volatiles produced by the decay process (McKemey et al., 2004), although $P$. melanarius has been found to orientate towards fresh slugs as well as following mucus trails (McKemey et al., 2004). Carabus nemoralis has also been found to follow mucus of D. reticulatum (Ayre, 1995).
Furthermore, the detection period for DNA from decaying slug in the gut of a predator was very similar compared to live slugs (Foltan et al., 2005). This means that the beetles testing positive for prey consumption in the present study may be from feeding on dead as well as live slugs. However, as Sunderland (1996) and Juen \& Traugott (2005) state, carrion may attract predators and may even signal that living prey is also available (Griffith et al., 1985; Chiverton, 1988; Winder et al., 1994). Furthermore, slug-positive beetles in the present study were clearly linked with the density of juvenile slugs in the spring, which suggests that predation is probably the main explanation for these results.

Future work should focus more on spatial rather than temporal data to further test the hypothesis that carabid beetles like $C$. nemoralis feed on slugs in proportion to numbers and biomass present. It may be possible to enhance the effectiveness of carabids as slug control agents by habitat management (Pickett \& Bugg, 1998). Provision of shelters and overwintering sites, lowering the amount of indiscriminate pesticides used as well as manipulating carabid activity by semiochemicals, may all have potential (Altieri et al., 1982; Kromp, 1999; Halaj et al., 2000; Symondson et al., 2002b). However, predator-prey interactions are complex and affected by additional factors, such as microhabitat structure, feeding history, cannibalism, fertilizers, crop, season and alternative prey (Symondson et al., 2002b). On the other hand, native predators, including carabids, are clearly able to suppress or reduce indigenous and exotic pests (Sunderland, 2002; Symondson et al., 2002b), and future studies should explore the efficiency of biological control of slugs.

\section{Acknowledgements}

We are very grateful to Heike Baldeweg, Stine Beate Balevik, Kathrin Bockmühl and Robin Corrià for assisting in sampling of beetles and slugs. Sincere thanks to Raul Ramirez for dissecting most of the beetles. We also thank Knut Helge Jensen for help with the statistics, and many thanks to Daniel Read and Michael Traugott, who gave valuable comments and suggestions. This study was partly funded by the University of Bergen and the Norwegian Research Council.

\section{References}

Adis, J. (1979) Problems of interpreting arthropod sampling with pitfall traps. Zoologischer Anzeiger 202, 177-184.

Agusti, N., Shayler, S.P., Harwood, J.D., Vaughan, I.P., Sunderland, K.D. \& Symondson, W.O.C. (2003) Collembola as alternative prey sustaining spiders in arable ecosystems: prey detection within predators using molecular markers. Molecular Ecology 12, 3467-3475.

Altieri, M.A., Hagen, K.S., Trujillo, J. \& Caltagirone, L.E. (1982) Biological control of Limax maximus and Helix aspersa by indigenous predators in a daisy field in central coastal California. Acto Oecologia/Oecologia Applicata 3, 387-390.

Anderson, R. (2005) An annotated list of the non-marine Mollusca of Britain and Ireland. Journal of Conchology 38, 607-637.

Ayre, K. (1995) Evaluation of carabids as predators of slugs in arable land. PhD thesis, University of Newcastle upon Tyne, Newcastle, UK.

Ayre, K. (2001) Effect of predator size and temperature on the predation of Deroceras reticulatum (Müller) (Mollusca) by carabid beetles. Journal of Applied Entomology 125, 389-395. 
Bailey, S.E.R. (2002) Molluscicidal baits for control of terrestrial gastropods. pp. 33-54 in Barker, G.M. (Ed.) Molluscs as Crop Pests. Wallingford, UK, CABI Publishing.

Barker, G.M. (2002) Molluscs as Crop Pests. Wallingford, UK, CABI Publishing.

Begon, M., Harper, J.L. \& Townsend, C.R. (2000) Ecology. 3rd edn. Oxford, UK, Blackwell Science.

Bohan, D.A., Bohan, A.C., Glen, D.M., Symondson, W.O.C., Wiltshire, C.W. \& Hughes, L. (2000) Spatial dynamics of predation by carabid beetles on slugs. Journal of Animal Ecology 69, 367-379.

Bolker, B.M., Brooks, M.E., Clark, J.C., Geange, S.W., Poulsen, J. R., Stevens, M.H.H. \& White, J-S.S. (2008) Generalized linear mixed models: a practical guide for ecology and evolution. Trends in Ecology and Evolution 24, 127-135.

Calder, C.R., Harwood, J.D. \& Symondson, W.O.C. (2005) Detection of scavenged material in the guts of predators using monoclonal antibodies: a significant source of error in measurement of predation? Bulletin of Entomological Research 95, 57-62.

Chen, Y., Giles, K.L., Payton, M.E. \& Greenstone, M.H. (2000) Identifying key cereal aphid predators by molecular gut analysis. Molecular Ecology 9, 1887-1898.

Chiverton, P.A. (1988) Searching behaviour and cereal aphid consumption by Bembidion lampros and Pterostichus cupreus, in relation to temperature and prey density. Entomologia Experimentalis et Applicata 47, 173-182.

de Leon, J.H., Fournier, V., Hagler, J.R. \& Daane, K.M. (2006) Development of molecular diagnostic markers for sharpshooters Homalodisca coagulata and Homalodisca liturata for use in predator gut content examinations. Entomologia Experimentalis et Applicata 119, 109-119.

Dodd, C.S. (2004) Development and optimisation of PCR-based techniques in predator gut analysis. PhD thesis, Cardiff University, Cardiff, UK.

Dolmen, D. \& Winge, K. (1997) Boasneglen (Limax maximus) og iberiasneglen (Arion lusitanicus) i Norge; utbredelse, spredning og skadevirkninger (In Norwegian). 'Limax maximus and Arion lusitanicus in Norway: distribution, expansion and injurious effects.' Report 4, 4-24. Zoological series, Trondheim, Norway, Vitenskapsmuseet.

Evans, M.E.G. \& Forsythe, T.G. (1985) Feeding mechanisms and their variation in form of some adult ground-beetles (Coleoptera: Caraboidea). Journal of Zoology 206, 113-143.

Folmer, O., Black, M., Hoeh, W., Lutz, R. \& Vrijenhoek, R. (1994) DNA primers for amplification of mitochondrial cytochrome c oxidase subunit I from diverse metazoan invertebrates. Molecular Marine Biology and Biotechnology 3, 294-299.

Foltan, P., Sheppard, S.K., Konvicka, M. \& Symondson, W.O.C. (2005) The significance of facultative scavenging in generalist predator nutrition: detecting decayed prey in the guts of predators using PCR. Molecular Ecology 14, 4147-4158.

Greenstone, M.H., Rowley, D.L., Weber, D.C., Payton, M.E. \& Hawthorne, D.J. (2007) Feeding mode and prey detectability half-lives in molecular gut-content analysis: an example with two predators of the Colorado potato beetle. Bulletin of Entomological Research 97, 201-209.

Griffith, E., Wratten, S.D. \& Vickerman, G.P. (1985) Foraging by the carabid Agonum dorsale in the field. Ecological Entomology 10, 181-189.

Grimm, B., Paill, W. \& Kaiser, H. (2000) Daily activities of the pest slug Arion lusitanicus. Journal of Molluscan Studies 66, 125-130.

Hagley, E.A.C., Holliday, N.J. \& Barber, D.R. (1982) Laboratory studies of the food preferences of some orchard carabids (Coleoptera: Carabidae). Canadian Entomologist 114, 431-437.

Halaj, J., Cady, A.B. \& Uetz, G.W. (2000) Modular habitat refugia enhance generalist predators and lower plant damage in soybeans. Environmental Entomology 29, 383-393.

Hall, T.A. (1999). BIOEDIT: a user-friendly biological sequence alignment editor and analysis program for Windows 95/98/ NT. Nucleic Acids Symposium Series 41, 95-98.

Harper, G.L., King, R.A., Dodd, C.S., Harwood, J.D., Glen, D.M., Bruford, M.W. \& Symondson, W.O.C. (2005) Rapid screening of invertebrate predators for multiple prey DNA targets. Molecular Ecology 14, 819-827.

Harwood, J.D., Desneux, N., Yoo, H.J.S., Rowley, D.L., Greenstone, M.H., Obrycki, J.J. \& O'Neil, R.J. (2007) Tracking the role of alternative prey in soybean aphid predation by Orius insidiosus: a molecular approach. Molecular Ecology 16, 4390-4400.

Hatteland, B.A., Grutle, K., Mong, C.E., Skartveit, J., Symondson, W.O.C. \& Solhøy, T. (2010) Predation by beetles (Carabidae, Staphylinidae) on eggs and juveniles of the Iberian slug Arion lusitanicus in the laboratory. Bulletin of Entomological Research 100, 559-567.

Hengeveld, R. (1980a) Polyphagy, oligophagy and food specialisation in ground beetles (Coleoptera, Carabidae). Netherlands Journal of Zoology 30, 564-584.

Hengeveld, R. (1980b) Qualitative and quantitative aspects of the food of ground beetles (Coleoptera, Carabidae): A review. Netherlands Journal of Zoology 30, 555-563.

Hofsvang, T. (2003) Snegler som skadedyr på planter (Slugs as plant pests). Grønn Kunnskap 7, 10 pp. (in Norwegian).

Holland, J.M. (2002) Agroecology of Carabid Beetles. Andover, UK, Intercept.

Hoogendoorn, M. \& Heimpel, G.E. (2001) PCR-based gut content analysis of insect predators: using ribosomal ITS-1 fragments from prey to estimate predation frequency. Molecular Ecology 10, 2059-2067.

Juen, A. \& Traugott, M. (2005) Detecting predation and scavenging by DNA gut-content analysis: a case study using a soil insect predator-prey system. Oecologia 142, 344-352.

Juen, A. \& Traugott, M. (2006) Amplification facilitators and multiplex PCR: Tools to overcome PCR-inhibition in DNA-gut-content analysis of soil-living invertebrates. Soil Biology E Biochemistry 38, 1872-1879.

Keane, R.M. \& Crawley, M.J. (2002) Exotic plant invasions and the enemy release hypothesis. Trends in Ecology and Evolution 17, 164-170.

King, R.A., Read, D.S., Traugott, M. \& Symondson, W.O.C. (2008) Molecular analysis of predation: a review of best practice for DNA-based approaches. Molecular Ecology 17, 947-963.

King, R.A., Moreno-Ripoll, R., Agustí, N., Shayler, S.P., Bell, J.R., Bohan, D.A. \& Symondson, W.O.C. (2010a) Multiplex reactions for the molecular detection of predation on pest and non-pest invertebrates in agroecosystems. Molecular Ecology Resources, doi: 10.1111/j.17550998.2010.02913.x

King, R.A., Vaughan, I.P., Bell, J.R., Bohan, D.A. \& Symondson, W.O.C. (2010b) Prey choice by carabid beetles feeding on an earthworm community analysed using species- and lineage-specific PCR primers. Molecular Ecology 19, 1721-1732.

Kromp, B. (1999) Carabid beetles in sustainable agriculture: a review on pest control efficacy, cultivation impacts and 
enhancement. Agriculture, Ecosystems and Environment 74, 187-228.

Langan, A.M., Taylor, A. \& Wheater, C.P. (2004) Effects of metaldehyde and methiocarb on feeding preferences and survival of a slug predator (Pterostichus melanarius (F.): Carabidae, Pterostichini). Journal of Applied Entomology 128, 51-55.

Lindroth, C.H. (1985) The Carabidae (Coleoptera) of Fennoscandia and Denmark 1. Fauna Entomologica Scandinavica 15, $225 \mathrm{pp}$.

Luff, M.L. (1982) Population dynamics of Carabidae. Annals of Applied Biology 101, 164-170.

Luff, M.L. (1987) Biology of polyphagous ground beetles in agriculture. Agricultural Zoology Reviews 2, 237-278.

Luff, M.L. (2002) Carabid assemblage organization and species composition. pp. 41-79 in Holland, J.M. (Ed.) The Agroecology of Carabid Beetles. Andover, UK, Intercept.

Lövei, G.L. \& Sunderland, K.D. (1996) Ecology and behaviour of ground beetles (Coleoptera: Carabidae). Annual Review of Entomology 41, 231-256.

Ma, J., Li, D., Keller, M., Schmidt, O. \& Feng, X. (2005) A DNA marker to identify predation of Plutella xylostella (Lep., Plutellidae) by Nabis kinbergii (Hem., Nabidae) and Lycosa sp. (Aranaea, Lycosidae). Journal of Applied Entomology 129, 330-335.

McKemey, A.R., Symondson, W.O.C., Glen, D.M. \& Brain, P. (2001) Effects of slug size on predation by Pterostichus melanarius (Coleoptera: Carabidae). Biocontrol Science and Technology 11, 81-91.

McKemey, A.R., Symondson, W.O.C. \& Glen, D.M. (2003) Predation and prey size choice by the carabid beetle Pterostichus melanarius (Coleoptera: Carabidae): the dangers of extrapolating from laboratory to field. Bulletin of Entomological Research 93, 227-234.

McKemey, A.R., Glen, D.M. \& Symondson, W.O.C. (2004) How does a carabid predator find aggregations of slugs in the field? Electroantennograms and behavioural assays suggest chemical cues. Bulletin of Entomological Research 94, 235-244.

Mitchell, C.E. \& Power, A.G. (2003) Release of invasive plants from fungal and viral pathogens. Nature 421, 625-627.

Oberholzer, F. \& Frank, T. (2003) Predation by the carabid beetles Pterostichus melanarius and Poecilus cupreus on slugs and slug eggs. Biocontrol Science and Technology 13, 99-110.

Paill, W. (2000) Slugs as prey for larvae and imagines of Carabus violaceus L. (Coleoptera, Carabidae). pp. 221-227 in Brandmayr, P., Lövei, G.L., Brandmayr, T.Z., Casale, A., Vigna Taglianti, A. (Eds) Natural History and Applied Ecology of Carabid Beetles. Sofia, Bulgaria, Pensoft Publishers.

Paill, W. (2004) Slug feeding in the carabid beetle Pterostichus melanarius: seasonality and dependence on prey size. Journal of Molluscan Studies 70, 203-205.

Paill, W., Backeljau, T., Grimm, B., Kastberger, G. \& Kaiser, H. (2002) Isoelectric focusing as a tool to evaluate carabid beetles as predatory agents of the pest slug Arion lusitanicus. Soil Biology and Biochemistry 34, 1333-1342.

Pakarinen, E. (1994) Autotomy in arionid and limacid slugs. Journal of Molluscan Studies 60, 19-23.

Pickett, C.H. \& Bugg, R.L. (1998) Enhancing Biological Control: Habitat Management to Promote Natural Enemies of Agricultural Pests. Berkeley, USA, University of California Press.

R Development Core Team (2008) R: A language and environment for statistical computing. Vienna, Austria, R Foundation for Statistical Computing. Available online at http://www.R-project.org.
Read, D.S., Sheppard, S.K., Bruford, M.W., Glen, D.M. \& Symondson, W.O.C. (2006) Molecular detection of predation by soil micro-arthropods on nematodes. Molecular Ecology 15, 1963-1972.

Rozen, S. \& Saletsky, H.J. (1996-1998) PRIMER 3 on the www for general users and for biologist programmers. pp. 365-386 in Krawetz, S. (Ed.) Bioinformatics Methods and Protocols: Methods in Molecular Biology. New Jersey, USA, Humana Press, Totowa.

Spence, J.R. \& Niemelä, J.K. (1994) Sampling carabid assemblages with pitfall traps: the madness and the method. Canadian Entomologist 126, 881-894.

Sunderland, K.D. (1996) Progress in quantifying predation using antibody techniques. pp. 419-455 in Symondson, W.O.C. \& Liddell, J.E. (Eds) The Ecology of Agricultural Pests, Biochemical Approaches. London, UK, Chapman \& Hall.

Sunderland, K.D. (2002) Invertebrate pest control by carabids. pp. 165-214 in Holland, J.M. (Ed.) The Agroecology of Carabid Beetles. Andover, UK, Intercept.

Symondson, W.O.C. (2002) Molecular identification of prey in predator diets. Molecular Ecology 11, 627-641.

Symondson, W.O.C. (2004) Coleoptera (Carabidae, Staphylinidae, Lampyridae, Drilidae and Silphidae) as predators of terrestrial gastropods. pp. 37-84 in Barker, G.M. (Ed.) Natural Enemies of Terrestrial Molluscs. Oxford, UK, $\mathrm{CAB}$ International.

Symondson, W.O.C., Glen, D.M., Wiltshire, C.W., Langdon, C.J. \& Liddell, J.E. (1996) Effects of cultivation techniques and methods of straw disposal on predation by Pterostichus melanarius (Coleoptera: Carabidae) upon slugs (Gastropoda: Pulmonata) in an arable field. Journal of Applied Ecology 33, 741-753.

Symondson, W.O.C., Glen, D.M., Ives, A.R., Langdon, C.J. \& Wiltshire, C.W. (2002a) Dynamics of the relationship between a generalist predator and slugs over five years. Ecology 83, 137-147.

Symondson, W.O.C., Sunderland, K.D. \& Greenstone, M.H. (2002b) Can generalist predators be effective biocontrol agents? Annual Review of Entomology 47, 561-594.

Szyszko, J., Gryuntal, S. \& Schwerk, A. (2004) Differences in locomotory activity between male and female Carabus hortensis (Coleoptera: Carabidae) in a pine forest and a beech forest in relation to feeding state. Environmental Entomology 33, 1442-1446.

Thiele, H.U. (1977) Carabid Beetles in their Environments. Berlin, Germany, Springer Verlag.

Torchin, M.E., Lafferty, K.D., Doubson, A.P., McKenzie, V.J. \& Kuris, A.M. (2003) Introduced species and their missing parasites. Nature 421, 628-630.

Traugott, M. \& Symondson, W.O.C. (2008) Molecular analysis of predation on parasitized hosts. Bulletin of Entomological Research 98, 223-231.

Turin, H., Penev, L., Casale, A., Arndt, E., Assmann, T., Makarov, K., Mossakowski, D., Szél, G. \& Weber, F. (2003) Species accounts. pp. 151-284 in Turin, H., Penev, L., Casale, A. (Eds) The Genus Carabus in Europe: A Synthesis. Sofia, Bulgaria, Pensoft Publishers.

von Berg, K., Traugott, M., Symondson, W.O.C. \& Scheu, S. (2008a) The effects of temperature on detection of prey DNA in two species of carabid beetle. Bulletin of Entomological Research 98, 263-269.

von Berg, K., Traugott, M., Symondson, W.O.C. \& Scheu, S. (2008b) Impact of abiotic factors on predator-prey interactions: DNA-based gut content analysis in a 
microcosm experiment. Bulletin of Entomological Research 98, 257-261.

von Proschwitz, T. (1992) Den spanska skogsnigeln Arion lusitanicus Mabille-en art i snabb spridning med människan i Sverige. Göteborgs Naturhistoriska Museum 1992, 35-42 (with English summary: The Spanish slug Arion lusitanicus Mabille - an anthropochorous slug species spreading rapidly in Sweden).

von Proschwitz, T. (1994) Oxychilus cellarius (Müller) and Oxychilus draparnaudi (Beck) as predators on eggclutches of Arion lusitanicus Mabille. Journal of Conchology 35, 183-185.

von Proschwitz, T. (1997) Arion lusitanicus Mabille and A. rufus (L.) in Sweden: A comparison of occurrence, spread and naturalization of two alien slug species. Heldia 4, 137-138. von Proschwitz, T. \& Winge, K. (1994) Iberiaskogsnegl - en art på spredning i Norge. (The Iberian slug - a species spreading in Norway.) Fauna 47, 195-203. (in Norwegian).

Weber, F. \& Heimbach, U. (2001) Behavioural, reproductive and developmental seasonality in Carabus auronitens and Carabus nemoralis (Col., Carabidae). Mitteilungen aus der Biologischen Bundesanstalt für Land- und Forstwirtschaft. Berlin-Dahlem, Germany, Berlin Heft 382.

Winder, L., Hirst, D.J., Carter, N., Wratten, S.D. \& Sopp, P.I. (1994) Estimating predation of the grain aphid Sitobion avenae by polyphagous predators. Journal of Applied Ecology 31, 1-12.

Zaidi, R.H., Jaal, Z., Hawkes, N.J., Hemingway, J. \& Symondson, W.O.C. (1999) Can multiple-copy sequences of prey DNA be detected amongst the gut contents of invertebrate predators? Molecular Ecology 8, 2081-2087. 